\title{
Children's exceptional minds as socio-economic resource
}

\author{
Andrea Graus (*) y Annette Mülberger (**) \\ $\left({ }^{*}\right) \quad$ orcid.org/0000-0002-9513-0048. Centre Alexandre Koyré, Centre National de la Recherche \\ Scientifique. andrea.graus@cnrs.fr \\ (**) orcid.org/0000-0002-7260-9734. Theory \& History of Psychology, Faculty of Social and \\ Behavioural Sciences, Rijksuniversiteit Groningen. a.c.mulberger@rug.nl
}

Dynamis

[0211-9536] 2020; 40 (2): 285-297

http://dx.doi.org/10.30827/dynamis.v40i2.17967
Fecha de recepción: 4 de octubre de 2020

Fecha de aceptación: 10 de noviembre de 2020

\section{Intelligence moving to the forefront}

This special issue entitled «Managing giftedness in contemporary society» ${ }^{1}$ analyzes how the category of giftedness has been mobilized in different areas - education, mental testing, and childrearing — to manage, classify, nurture, and even exploit commercially children in Europe and America in the nineteenth and twentieth centuries. In the first decades of the twentieth century, educators, pedagogical experts, pedologists, and psychologists, together with some physicians, drew attention to the existence of children whose intelligence and talents exceeded the average. The agendas that motivated their studies varied, including eugenics, mental hygiene, professional guidance, and an attempt to improve schooling while increasing educational efficiency. Intelligence tests became a widespread tool, but as several articles have demonstrated, they were not the only method to explore children's minds and capacities. In the particular case of child prodigies, psychological examinations were expected to contribute knowledge about mental traits, such as memory, because in

1. This special issue is based on a panel we organized in 2019 for the conference of the European Society for the History of the Human Sciences. This research has received funding from the European Union's Horizon 2020 research and innovation program under the Marie SklodowskaCurie grant agreement no. 793654. 
these cases such traits appeared magnified ${ }^{2}$. The present volume aims to shed light on the social and scientific agendas supporting the use of categories like «child prodigy» and «gifted child», and to explore the impact they achieved beyond the limits of psychological science.

Giftedness was a rather new psychological term that began to be more widely used in the twentieth century. Its emergence was linked to a growing interest in assessing animal and human intelligence in the previous century. Evolutionary theory played a key role because it depicted human beings as a species that, in the long run, had been able to prevail over others in the fight for resources. Following Darwin's theory, human dominance was due neither to physical strength nor to a superior ability to flee from predators, but to a psychological characteristic linked to manual and intellectual skills. In this context, psychologists and biologists began to use more widely the concept of intelligence to designate intellectual superiority, which they associated with the human capacity to adapt to changing and challenging environments in which it was not easy to access food and other scarce resources.

The scientific attempt to determine differences in the degree of intelligence in human beings was a novelty of the nineteenth century. This attempt was linked to a growing concern among medical doctors with cases where they detected lower intellectual abilities that they considered pathological. Medical texts of the time, such as that of the French psychiatrist Félix Voisin (1794-1872), expressed this point of view ${ }^{3}$. In 1843, Voisin defined human intelligence as an attribute that varied from individual to individual on a scale ranging from «the excellence of genius and the most sublime elevation of the soul to the most repulsive image of intellectual and moral idiocy» ${ }^{4}$. Physicians and psychiatrists like Voisin focused, above all, on the management of persons whom they diagnosed to have a certain lack of intelligence.

Almost three decades later, Darwin's cousin, the British aristocrat Francis Galton (1822-1911) — who was credited with an exceptional intelligence-

2. Carroy, Jacqueline; Plas, Régine. The origins of French experimental psychology: experiment and experimentalism. History of the Human Sciences; 1996, 9 (1): 78-84. Carson, John. Minding matter/mattering mind: knowledge and the subject in nineteenth-century psychology. Studies in History and Philosophy of Biological and Biomedical Sciences; 1999, 30 (3): 345-376. Nicolas, Serge; Gyselinck, Valérie. Introduction. Les grands calculateurs mentaux. In: Nicolas, Serge, Gyselinck, Valérie, eds. Les calculateurs prodiges. Leur histoire et leur psychologie. Paris: L'Harmattan; 2016, p. 5-16.

3. Voisin, Félix. De l'idiotie chez les enfants. Paris: J.-B. Baillière; 1843.

4. Doron, Claude-Olivier. Félix Voisin and the genesis of abnormals. History of Psychiatry; 2015, 26 (4): $387-403$. 
presented a genealogical study of genius in his book Hereditary Genius (1869). He tried to demonstrate how children inherited talents and intellectual capacities from their parents, along with other physical and psychological traits. Contrary to the predominant pathological understanding of precocity, he viewed the precocious child as well-balanced and full of promise for the future of society ${ }^{5}$. In the 1880 s, Galton undertook further empirical studies on genius using anthropometry to measure individual differences. At the same time, he proposed eugenics as a program to manage the procreation of the human species to ensure that only healthy persons with desirable traits would have children.

Galton's focus contrasted with the concerns of some physicians and criminologists to diagnose idiocy, a category that in some cases was closely linked to genius. The Italian psychiatrist Cesare Lombroso (1835-1909) and his followers considered geniuses, and particularly child geniuses, as pathological manifestations of madness and degeneration that had to be carefully guarded ${ }^{6}$. From this point of view, the «genius» and the «idiot» were two opposing characters that went hand in hand, symbolizing a kind of pathological intelligence (exaggerated or deficient) present in the general population. Later classifications of these sectors of the population -located at the extreme ends of the Gaussian bell- referred to these conditions as infra- and supranormal.

While in the nineteenth century experts defined the genius in opposition to the idiot, in the early twentieth century they viewed giftedness as a mental condition and counterpart to feebleness. Giftedness was thereby linked to notions of talent and high IQ, while the notion of mental feebleness derived from the idea that there existed mild (pre-)levels of idiocy, for which concepts such as mental retardation or deficit were often used. Against the backdrop of social statistics and psychometrics, the gifted and the feeble-minded began to be understood as a deviation from $«$ normality» ${ }^{7}$, defined in intellectual terms by the average intelligence measured by a test. Experts situated gifted children toward the upper extreme of a normal curve that represented levels

5. Shuttleworth, Sally. The mind of the child. Child development in literature, science, and medicine, 1840-1900. Oxford: Oxford University Press; 2010.

6. Lombroso, Cesare. The man of genius. London: Walter Scott; 1891.

7. Hacking, Ian. The normal state. In: The taming of chance. Cambridge University Press; 1990, p. 160-169. 
of intelligence (or of a certain talent) in comparison with other children of their age or with the general population ${ }^{8}$.

In this context, being gifted became a way to refer to a human being presenting a high intelligence (frequently measured through the IQ), or demonstrating superior performance in particular artistic or mental tasks, such as playing the piano or solving mathematical problems. Although there was no universal scholarly agreement on how to define giftedness, a consensus existed on why this category was important. Identifying gifted children became a vital part of managing potential human resources. While the management of so-called idiocy had taken place since the nineteenth century ${ }^{9}$, the utilitarian view of giftedness became predominant in the first decades of the twentieth century. It contrasted sharply with the previous romantic and wondrous understandings of the innate genius ${ }^{10}$.

Historians of science have explored the role of pioneers such as Robert Goddard (1882-1945), Lewis Terman (1877-1956), and others, who were the first to use and promote intelligence testing in the United States. Works by scholars such as Michael Sokal and Leila Zenderland contributed to the development of a social history of intelligence in America, a much-needed approach to understanding the attitudes and politics that supported the use of IQ tests in this context ${ }^{11}$. Comparing the American and French Republics, John Carson showed how each country used different means to select their most talented individuals and how this practice formed a part of their meritocratic policy. While France established a very selective, yet class-privileged, school system, intelligence tests gained popularity in the United States after the First World War because they were viewed as an objective tool to classify intellectual merit ${ }^{12}$. As Annette Mülberger advocated in a special issue of History of Psychology, contextualized approaches help

8. Mengal, Paul. Le désenchantement du génie: psychologie des surdoués. In: Sacquin, Michel, ed. Le printemps des génies. Les enfants prodiges. Paris: Bibliothèque Nationale/Robert Laffont; 1993, p. 263-275.

9. Lachapelle, Sofie. Educating idiots: utopian ideals and practical organization regarding idiocy inside nineteenth-century French asylums. Science in Context; 2007, 20 (4): 627-648.

10. Jefferson, Ann. Genius in France. An idea an its uses. Princeton and Oxford: Princeton University Press; 2015.

11. Sokal, Michael, ed. Psychological testing and American Society (1890-1930). New Brunswick, NJ: Rutgers University; 1987. Zenderland, Leila. Measuring minds: Henry Herbert Goddard and the origins of American mental testing. Cambridge: Cambridge University Press; 1998.

12. Carson, John. The measure of merit: talents, intelligence, and inequality in the French and American republics, 1750-1940. Princeton: Princeton University Press; 2007. 
realize how mental testing was applied in different local contexts. Focusing on less explored national contexts such as those of Italy, Spain, Brazil, and the USSR, the contributors to the monographic issue showed that a wide range of mental tests circulated during the first half of the twentieth century to manage and classify children. They also explored the role of historical actors such as primary school teachers, whose involvement in the testing movement scholars have often overlooked ${ }^{13}$.

\section{The child as an object of study and protection}

Within the historical background outlined above, the child started to become an object of study. On the one hand, developmental psychology and pedology emerged as sciences dealing with the child and, in the latter case, more precisely with the child's evolution. On the other hand, new pedagogical currents such as the active school and the Montessori school, as well as the child study movement, reflected a broader concern about children and their education that had been growing since the end of the nineteenth century within western societies.

Historical accounts often cite Charles Darwin's A Biographical Sketch of an Infant (1877) and Wilhelm Preyer's Die Seele des Kindes (1882) as signs of a renewed interest in ontogenetic development. Historian of psychology Sheldon White presented a periodization of the programmatic inquiry that followed these early contributions, beginning with the child study movement (1894-1904) ${ }^{14}$. Gerrit Breeuwsma pointed out that this movement was an essential step toward improving children's welfare and was, therefore, seen by many as a reform movement, enhancing society's awareness about the need to care for and protect children ${ }^{15}$. This initiative was mainly the work of the American psychologist G. Stanley Hall (1844-1924), who pursued a systematic and naturalistic inquiry into child development using questionnaires on

13. Mülberger, Annette, ed. Mental testing after 1905: uses in different local contexts (Special issue). History of Psychology; 2014, 17 (3): 177-255.

14. White, Sheldon. Developmental psychology in a world of designed institutions. In: Koops, Willem and Zuckerman, Michael, eds. Beyond the century of the child. Cultural history and developmental psychology. Philadelphia: University of Pennsylvania Press; 2003, p. 204-223.

15. Breeuwsma, Gerrit. The nephew of an experimentalist: ambivalences in developmental thinking. In: Koops, Willem and Zuckerman, Michael, eds. Beyond the century of the child. Cultural history and developmental psychology. Philadelphia: University of Pennsylvania Press; 2003, p. 183-203. 
topics such as children's play, language, and art, which he distributed among teachers and mothers. Hall used the data gathered through this pioneering method to elaborate an evolutionary account of human development. As White stated, «The discussions and numerous practical recommendations in Hall's [book] Adolescence were based on the premise that this evolutionary picture of children's development could offer scientifically based guidance to individuals concerned with the upbringing and education of children» ${ }^{16}$.

Despite the social significance of Hall's attempts and his reputation as a scientist, some of his colleagues immediately criticized him. Critics rejected Hall's «messy use» of the questionnaires filled out by mothers and teachers and considered the data unreliable. According to psychologists Hugo Münsterberg (1863-1916) and James Sully (1842-1923), mothers were too sentimental and too much involved in nurturing their offspring to be able to offer any objective (scientific) observations. Moreover, they found Hall's interpretations arbitrary and instead called for laboratory-based studies.

Researchers undertook larger cooperative projects to study children, grouped under the «child development movement» label between 1917 and $1950^{17}$. At the same time, they established several multidisciplinary institutes and centers on child studies. One of the most well-known initiatives of the period was the research supported by the American social scientist Lawrence K. Frank (1890-1968), the director of both the Laura Spelman Rockefeller Memorial and the child-development program of the Rockefeller Foundation between 1929 and $1933^{18}$. The psychologist Edward Thorndike (1874-1949) also promoted an ambitious research program in educational psychology in the United States. In the field of psychoanalysis, Anna Freud (1895-1982) and Melanie Klein (1882-1960) led the research. These two psychoanalysts moved beyond Freud's theories and focused more on emotional conflicts in childhood and child development.

White's periodization breaks down when looking beyond the United States because a growing interest in child development studies became prevalent during the first two decades of the twentieth century in France, Switzerland, Belgium, Germany, and other nations ${ }^{19}$. The studies of the French

16. White, n. 14, p. 214

17. White, n. 14, p. 214.

18. For more information on this, please see Bryson, Dennis R. Socializing the young: The role of foundations, 1923-1941. Westport, CT: Bergin \& Garvey; 2002.

19. Ottavi, Dominique. De Darwin à Piaget: pour une histoire de la psychologie de l'enfant. Paris: CNRS Éditions; 2001. 
psychologist Alfred Binet (1857-1911) and his collaborators at the Société Libre pour l'Étude Psychologique de l'Enfant stand out; but the German psychologists Ernst Meumann (1862-1915) and William Stern (1871-1938) also contributed substantially to foster developmental and educational psychology, now a recognized field of specialization. For several reasons, the 1920s and 1930s can be considered the zenith of the child development movement in Europe and America. Those decades witnessed the foundation of journals such as Child Development, and the Austrian psychologist Heinz Werner (1890-1964) published his book Einfuehrung in die Entwicklung spsychologie [Introduction to Developmental Psychology](1926) - an earlier version of his most well-known book Comparative Psychology of Mental Development (1940). Other psychologists such as Jean Piaget (1896-1980) in Geneva and Lev Vygotsky (1896-1934) in Moscow completed the main corpus of research on child development, for which they would be internationally known and cited, during these same decades.

\section{Social anxiety about the feeble-minded child}

This historiography on intelligence testing demonstrates the social unease with the feeble-minded or abnormal child, the label that French psychologists Alfred Binet and Théodore Simon (1873-1961) popularized while developing the first intelligence test in 1905 . Until the early twentieth century, the category of feebleness was more socially relevant than that of giftedness. Against the backdrop of theories of degeneration, and the mental hygiene movement, identifying and treating feebleness in children became a priority in many European and American countries ${ }^{20}$. Their potential degenerative character gave new arguments to eugenics, especially in countries like the United States $^{21}$. In addition, authorities expected feeble-minded children, including girls, to be more likely to commit criminal acts ${ }^{22}$. Such pejorative definitions, paired with the determination of modern nations to raise good

20. Campos Marín, Ricardo, Martínez Pérez, José, \& Huertas García-Alejo, Rafael. Los ilegales de la naturaleza. Medicina y degeneracionismo en la España de la Restauración (1876-1923). Madrid: CSIC; 2000.

21. Ryan, Patrick J. Un natural selection: intelligence testing, eugenics, and American political cultures. Journal of Social History; 1997, 30 (3): 669-685.

22. Massin, Veerle. «Measuring Delinquency». The observation, scientific assessment and testing of delinqüent girls in 20th century Belgium. Journal of Belgian History; 2016, 46 (1): 104-132. 
citizens, placed the feeble-minded child at the center of social and political debates.

Throughout the twentieth century, the scientific study of these children spread from the medical to the educational field ${ }^{23}$. Historians of psychiatry Mercedes del Cura and Rafael Huertas explored how the definition of mental retardation changed with the advent of compulsory education and the use of intelligence tests in the school system. According to them, thanks to Binet and other psychologists, mental feebleness in children evolved from being a medico-psychiatric diagnosis to a psycho-pedagogical category that referred to children who did not adapt well to school ${ }^{24}$. Such an interpretation generated new alliances and new tensions in professional expertise among physicians, psychologists, and pedagogical experts ${ }^{25}$.

Social anxieties regarding the feeble-minded contributed to the passage of new laws for child protection. The history of education showed that experts expected the implementation of mandatory schooling in the late nineteenth century to reduce delinquency in children and young adults by taking them off the streets of the cities, and to offer working-class children better occupational opportunities by improving their mental and physical development ${ }^{26}$. Educational reformers helped convince the population of the necessity of regulating child labor as well, which led to new legislation. However, laws against child exploitation were only partially enforced ${ }^{27}$, and special regulations remained for children employed in domains such as the entertainment industry, where many child prodigies continued to make a living ${ }^{28}$.

Today, the understanding of mental feebleness has changed drastically from how it was understood in the nineteenth and early twentieth centuries,

Vetö, Silvana. Child delinquency and intelligence testing at Santiago's Juvenile Court, Chile, 1929-1942. History of Psychology; 2019, 22 (3): 244-265.

23. Wacjman, Claude. Enfants anormaux, inadaptés, handicapés: une continuité idéologique?. Vie Sociale; 2013, 4 (4): 159-176.

24. Huertas, Rafael, Del Cura, Mercedes. La categoría «infancia anormal» en la construcción de una taxonomía social en el primer tercio del siglo XX. Asclepio; 1996, 48 (2): 115-127.

25. Del Cura, Mercedes. Medicina y pedagogía. La construcción de la categoría «infancia anormal» en España (1900-1930). Madrid: CSIC; 2011.

26. Gillis, A.R. Institutional dynamics and dangerous classes: reading, writing, and arrest in nineteenthcentury France. Social Forces; 2004, 82 (4): 1303-1331. Guereña, Jean-Louis, Tiana, Alejandro, eds. Clases populares, cultura, educación, siglos XIX-XX. Madrid: Casa Velázquez, UNED; 1989.

27. Cunningham, Hugh, Viazzo, Pier Paolo, eds. Child labour in historical perspective, 1800-1985. Florence: UNICEF; 1996.

28. Colclough, Dyan. Child labor in the British Victorian entertainment industry, 1875-1914. London: Palgrave Mcmillan; 2016. 
abandoning pejorative terms such as «feeble-minded», «idiot», and «retarded ${ }^{29}$. Nevertheless, social and political concerns about intellectually disabled children endure. Educational and social reformers have made efforts in the last several decades to integrate intellectually disabled children into schools and communities. Most European and American countries have associations for such children, who counsel families, teachers, and policy-makers ${ }^{30}$.

\section{The gifted child: a person with special needs?}

Historical research on the gifted child is quite limited and has often been carried out by psychologists and educators working on giftedness today ${ }^{31}$. A thorough historical reappraisal of child giftedness is missing from the scholarship. Social and scientific concerns with giftedness have increased considerably since the 1920s. In popular culture, there has been a renewed fascination with child prodigies and new international interest in child stars, especially in the film industry ${ }^{32}$. Various media have published frequent stories on the lives and early achievements of talented and gifted children, shedding new light on child prodigies, while helping the public to understand better their needs and ways of thinking ${ }^{33}$.

During the early twentieth century, news about Lewis Terman's longitudinal studies on American children with high IQs, which began in 1921, spread throughout Europe ${ }^{34}$. According to sociologist Roblyn Rawlins, Terman and other psychologists who studied exceptional children, such as Leta Hollingworth (1886-1939), tried to overturn the association between intellec-

29. Schalock, Robert L., Luckasson, Ruth A., Shogren, Karrie A. The renaming of mental retardation: Understanding the change to the term intellectual disability. Intellectual and Developmental Disabilities; 2007, 45 (2): 116-124.

30. For example, the European Association for Mental Health in Persons with Intellectual Disability (EAMHID). There are also examples for the case of gifted children, such as the European Council for High Ability (ECHA).

31. Jolly, Jennifer L. A history of American gifted education. New York and London: Routledge; 2018. Robinson, Ann; Clinkenbeard, Pamela R. History of giftedness: perspectives from the past presage modern scholarship. In: Pfeiffer, Steven I., ed. Handbook of giftedness in children. Psycho-educational theory, research, and best practices. New York: Springer; 2008, p. 13-31.

32. O'Connor, Jane. The normal child and the exceptional child. In: The cultural significance of the child star. New York, London: Routledge; 2008, p. 13-37.

33. Bates, Stephen. The prodigy and the press: William James Sidis, anti-intellectualism and standards of success. Journalism and Mass Communication Quarterly; 2011, 88 (2): 374-397.

34. Terman, Lewis. Genetic studies of genius. Volume 1. Mental and physical traits of a thousand of gifted children. Standford: Standford University Press; 1926. 
tual precocity and pathology that had permeated the medico-psychological discourse of the nineteenth century. They argued that gifted children were well-balanced and emotionally stronger than the average child and portrayed them as a national resource. Therefore, they concluded, educators should identify such children and nurture them through enriched school curricula ${ }^{35}$. Scholars exploring the history of education such as Clementine Beauvais and Rupert Higham showed how, thanks to Terman and Hollingworth, educators began to think of the concept of potential as a property of precocious children - a high IQ being the objective measure of this potential ${ }^{36}$.

The historiography on the subject of child giftedness has focused mainly on some pioneering investigations carried out in the United States, under the influence of Galton's work and within the American school setting ${ }^{37}$. Leslie Margolin explored the early construction of the gifted child as an upper-middle-class white child, perceived as "personified goodness». This image contrasted with the working class «feeble-minded» child. Eugenics and theories of heredity influenced this elitist discourse on giftedness heavily and served to legitimize social discrimination and segregated education ${ }^{38}$. Jim Porter demonstrated how, within this context, researchers declared giftedness to be a natural category and gifted children, a precious minority. Following Terman's view, experts argued that neglecting the gifted child's special needs would threaten national progress. Such concerns led to important reforms in the school system after World War II ${ }^{39}$. As Wilfried Lignier

35. Rawlins, Roblyn. Raising «precocious» children: from nineteenth-century pathology to twentiethcentury potential. In: Beatty, Barbara; Cahan, Emily D.; Grant, Julia, eds. When science encounters the child. Education, parenting, and child welfare in 20th-century America. New York and London: Teachers College Press, p. 77-95.

36. Beauvais, Clémentine; Highman, Rupert. A reappraisal of children's «potential». Studies in Philosophy and Education; 2016, 35: 573-587.

37. Davis, Gary A.; Rimm, Sylvia B.; Del Siegle. Education of the gifted and talent. 6th ed. Essex: Pearson Education Limited; 2014; Kaufman, Scott Barry; Sternberg, Robert J. Conceptions of Giftedness. In: Pfeiffer, Steven I. editor. Handbook of giftedness in children: Psychoeducational theory, research, and best practices. Boston: Springer; 2008, p. 71-91; Tannenbaum, Abraham J. A history of giftedness in school and society. In: Heller, Kurt A.; Mönks, Franz J.; Sternberg, Robert J.; Subotnik, Rena F. editors. International handbook of giftedness and talent. 2nd ed. Oxford: Elsevier Science; 2000, p. 23-53.

38. Margolin, Leslie. Goodness personified: the emergence of gifted children. Social Problems; 1993, 40 (4): 510-532.

39. Porter, Jim Wynter. A «precious minority»: constructingthe «gifted» and «academically talented» student in the era of Brown v. Board of Education and the National Defense Education Act. Isis; 2017, 108, (3): 581-605. 
showed, similar developments took place in France during the second half of the twentieth century, including the coining of the term surdoué [intellectually gifted]. However, unlike the American case, the impulse for these educational reforms came from below, from families and civic associations devoted to gifted children ${ }^{40}$.

Since the 1980s, following the development of studies in giftedness and the rise of theories of multiple intelligences, IQ is no longer the sacrosanct indicator it used to be when Terman began studying gifted children. Many concepts, from high ability to talent to creativity, are now at the heart of research on giftedness ${ }^{41}$. However, the media continues to trivialize giftedness, portraying it as a desirable and almost unproblematic quality in children. Best-selling guidebooks for parents about raising a child genius ${ }^{42}$ and television shows where talented children compete reveal that fascination with the idea of giftedness, expressing itself in multiple ways, persists today.

\section{About this special issue}

The contributors to this special issue show that the malleability of the categories of giftedness and feebleness allowed a wide range of historical actors to adapt them to fit their agendas better. This reappraisal took place within the traditional fields of education and child psychology but also in less conventional domains, such as the entertainment and media industries. The studies in this issue explore the roles of experts (psychologists and pedagogical experts), as well as those of teachers, parents, and impresarios. They deal with different types of children, including gifted schoolchildren, child prodigies, and children classified as feeble-minded because of their class background and lack of educational opportunities. The authors show that, apart from intelligence, concepts such as talent, race, class, and gender were important in defining gifted and feeble-minded children, as well as child prodigies. The

40. Lignier, Wilfried. La petite noblesse de l'intelligence. Un sociologie des enfants surdoués. Paris: La Découverte; 2012.

41. Lubart, Todd, ed. Enfants exceptionnels: précocité intellectuelle, haut potential et talent. Rosnysous-Bois: Bréal; 2005, p. 16-20. Tourón, Javier. De la superdotación al talento. Evolución de un paradigma. In: Jiménez, Carmen, ed. Pedagogía diferencial. Diversidad y equidad. Madrid: Pearson Educación; 2004, 367-400.

42. For example, Fuller, Andrew. Unlocking your child's genius. How to discover and encourage your child's natural talents. Sydney: Finch; 2016. 
historical actors also mobilized an extensive and unusual number of theories, including original perspectives from psychoanalysis, Marxism, meritocracy, childrearing, and talent development. Overall, the contributors show that the history of giftedness in children is multifaceted and complex and that it cannot be reduced to a narrow understanding of intelligence.

In their study, Génesis Nuñez and Annette Mülberger address the identification and management of intellectually gifted students between the 1910s and the Second Republic in Spain. After a strong focus on feeble-minded children in the late nineteenth and early twentieth centuries, Spain, like many other European and American countries, became concerned with the identification of gifted children. The main goal was to provide an adequate education to a supposedly forgotten but precious minority to improve the country's human resources for the future. The task of identifying gifted children took place in primary schools and in professional guidance institutions. Different professionals were involved in defining and classifying schoolchildren: teachers, pedagogical experts, psycho-technicians, psychologists, and even politicians. The methods they employed for these identifications included adaptations from foreign intelligence tests and individual reports.

Focusing on the United States between 1920 and 1960, Kimberly Probolus examines how expert discourses on giftedness reached the wider public through the media and guidebooks for parents. This popularization of these scientific ideas shaped parental attitudes toward gifted children and fostered new childrearing styles. Experts encouraged parents to ensure the best educational opportunities for their child, which in turn increased competition and the development of programs for talented children and elite schools. According to Probolus, a system based on merit contributed to racial segregation in schools and classrooms. The rights of minorities to equal educational opportunities came into conflict with the perceived need for gifted (or unequal) education.

In her research, Andrea Graus examines the question of the general education of child prodigies in the nineteenth century. The contextual background is France, especially Paris, where child prodigies in classical music and mental calculation exhibited their talents in theatres, exclusive soirées, and learned societies. Graus explores the role of parents and impresarios in exploiting child prodigies commercially and argues that they intentionally postponed their elementary studies despite having the means to provide them with education. As a result, a majority of child prodigies were illiterate and showed high levels of ignorance outside their field of expertise. Their lack of 
general education became their main feebleness, preventing not only their full mental development but also the cultivation of their particular talent.

Intelligence tests have a long tradition as instruments to identify gifted and intellectually disabled individuals. However, just how intelligence is defined, and how the tests are adapted and applied, varies from context to context $^{43}$. In a final article, Victoria Molinari addresses this issue while focusing on the book Los Tests (1946) by Béla Székely, a Hungarian psychologist in Argentina. In a very particular mix, Székely used psychoanalysis and Marxism to conceptualize intelligence and personality testing. He attributed the cause of mental feebleness in children to class and economic conditions. Although he was marginalized in intellectual and psychoanalytic circles in Argentina, he was able to reach a lay audience, including teachers who gained access to psychological knowledge.

43. Mülberger, Annette. The need for contextual approaches to the history of mental testing. History of psychology; 2014, 17 (3): 177-86. 